\title{
Pituitary Stone: A Case Report and Review of the Literature
}

\section{Pitüiter Taş: Bir Olgu Sunumu ve Literatürün Gözden Geçirilmesi}

\author{
Necmettin TANRIOVER ${ }^{1}$, Baris KUCUKYURUK ${ }^{1}$, Esra HATIPOGLU², Nil COMUNOGLU³ \\ ${ }_{1}^{1}$ Istanbul University, Cerrahpasa Medical Faculty, Department of Neurosurgery, Istanbul, Turkey \\ 2Istanbul University, Cerrahpasa Medical Faculty, Internal Medicine, Division of Endocrinology, Istanbul, Turkey \\ ${ }^{3}$ Istanbul University, Cerrahpasa Medical Faculty, Department of Pathology, Istanbul, Turkey
}

Corresponding Author: Necmettin TANRIOVER / E-mail: nctan27@yahoo.com

\begin{abstract}
A 39-year-old male without any significant complaints or symptoms presented with a calcified lesion located at the sellar region. Total removal of the lesion has been achieved via an endoscopic endonasal transsphenoidal approach. Histopathological examination of the lesion revealed a pituitary stone.

This report describes the first pituitary stone formed within a plurihormonal pituitary adenoma and also differs from previous studies in means of chosen surgical method that is the first endoscopic approach to a pituitary stone. Additionally, by reviewing previous cases, a classification has been proposed and possible pathophysiological mechanisms behind this rare entity have been discussed.
\end{abstract}

KEYWORDS: Neuro-endoscopy, Pituitary adenoma, Pituitary stone, Prolactinoma, Transsphenoidal route

öz

Hiçbir şikayeti olmayan ve her hangi bir belirti saptanmayan 39 yaşında erkek hasta, sellar bölgede yerleşim gösteren kalsifiye olmuş bir kitle lezyonu ile başvurdu. Endoskopik endonasal transsfenoidal yol ile kitlenin tamamı tek seansta eksize edildi. Histopatolojik incelemede lezyonun bir pitüiter taş olduğu saptandı.

Bu rapor ile literatürde ilk defa pitüiter taşın bir plurihormonal hipofiz adenomunun içinde geliştiği bir olgu sunulmuştur. Ayrıca, bu olgu, tedavisinde tercih edilen cerrahi teknik açısından da önceki olgulardan ayrılmaktadır. Ek olarak; literatürde önceden bildirilmiş kısıtılı sayıdaki pitüiter taş olguları gözden geçirilerek bir sınıflama önerilmiştir ve bu nadir tanının ardında yatabilecek patofizyolojik mekanizmalar tartışılmıştır. ANAHTAR SÖZCÜKLER: Hipofiz adenomu, Nöroendoskopi, Pitüiter taş, Prolaktinoma, Transsfenoidal yol

\section{INTRODUCTION}

According to radiological series, up to $14 \%$ of pituitary adenomas may show calcifications, whereas this incidence may rise up to $25 \%$ in histological series $(7,20)$. However, large calcified intrasellar mass, defined as pituitary stone, is a distinct and rare type of calcareous deposits within a pituitary adenoma. So far, eighteen cases including the present case have been reported in the English literature $(2,3,5,7,11,13$ $16,18,20,23,25)$.

In this report, we present a unique case of a pituitary stone that originated from a plurihormonal pituitary adenoma showing immunreactivity for prolactin (PRL), thyroid stimulating hormone (TSH), and growth hormone (GH). Also, it differs from previously reported cases in terms of management of the lesion: this is the first pituitary stone case operated via fully endoscopic endonasal transsphenoidal route. Additionally, we provide a review of previous cases to discuss important clinical aspects and possible pathophysiological mechanisms behind this clinical phenomenon.

\section{CASE REPORT}

Thirty-nine year old male presented with chronic nonlocalizing headache. The patient had no remarkable medical and family history. At the time of admission, physical examination did not reveal any sign of neurological deficit or morphological changes. Magnetic resonance imaging (MRI) revealed a heterogenic sellar mass that was slightly hyperintense with sparse hypointense nodularity in the lesion on both T1- and T2-weighted images and was enhancing heterogeneously after gadolinium administration. The lesion was $15,6 \times 15.2 \times 13.7 \mathrm{~mm}$ in size and was showing minimal suprasellar extension but no invasion of the cavernous sinuses (Figure 1A-E). Computed tomography (CT) scan showed prominent calcifications at the periphery and center of the lesion (Figure 2A-D). Hormone studies revealed nothing abnormal except a slight decrease in IGF-1 level (Table I). Hence, the patient underwent removal of the lesion, which was preliminary diagnosed as a craniopharyngioma, via endoscopic endonasal transsphenoidal route. Intraoperatively, the lesion, which was gray-yellow in color and had stone-like consistency, was totally removed with the help of suction and 
ring-curettes (Figure 3A-D). Postoperative MRI and CT proved total removal of the lesion (Figure 4A-E). Postoperative course was uneventful, except central diabetes insipitus treated by desmopressin. Histopathological examination revealed a pituitary adenoma. Immunhistochemical staining showed

Table I: Preoperative Hormone Levels of the Patient

\begin{tabular}{|l|c|c|}
\hline Hormone & Patient's hormone level & Normal values \\
\hline PRL & $7.36 \mathrm{ng} / \mathrm{mL}$ & $4.1-18.4 \mathrm{ng} / \mathrm{mL}$ \\
\hline $\mathrm{GH}$ & $0.12 \mathrm{ng} / \mathrm{mL}$ & $0-4 \mathrm{ng} / \mathrm{mL}$ \\
\hline IGF-1 & $104 \mathrm{ng} / \mathrm{mL}$ & $254 \pm 7 \mathrm{ng} / \mathrm{mL}$ \\
\hline TSH & $0.89 \mathrm{mIU} / \mathrm{L}$ & $0.4-4.2 \mathrm{mIU} / \mathrm{L}$ \\
\hline fT3 & $2.18 \mathrm{pg} / \mathrm{mL}$ & $1.8-4.2 \mathrm{pg} / \mathrm{mL}$ \\
\hline fT4 & $1.23 \mathrm{ng} / \mathrm{dL}$ & $0.7-1.9 \mathrm{ng} / \mathrm{dL}$ \\
\hline ACTH & $7.85 \mathrm{pg} / \mathrm{mL}$ & $0-46 \mathrm{pg} / \mathrm{mL}$ \\
\hline Cortisol & $11.3 \mu \mathrm{g} / \mathrm{dL}$ & $3.7-19.4 \mu \mathrm{g} / \mathrm{dL}$ \\
\hline
\end{tabular}

predominantly PRL and TSH secreting cells in addition to sparse $\mathrm{GH}$ secreting cells (Figure $5 \mathrm{~A}, \mathrm{~B}$ ). Interestingly, dense dystrophic calcification areas were present all over the lesion proving the presence of a pituitary stone (Figure 5C,D).

\section{DISCUSSION}

We present a case of pituitary stone within a mix-type pituitary adenoma with multiple hormone secretion, consisting of PRL, $\mathrm{TSH}$, and GH. To our knowledge, this is the first case of a mixed hormone secreting pituitary adenoma harboring a pituitary stone that was removed via fully endoscopic endonasal transsphenoidal route.

Common calcifications in pituitary adenomas are found in two morphological types (2,20): First, egg shell-like calcifications outlining the periphery of the adenoma; second, nodular calcifications located at the center of the adenoma. The term pituitary stone stands as a radiological nomenclature for rare occasion of large calcareous deposits within a pituitary adenoma.
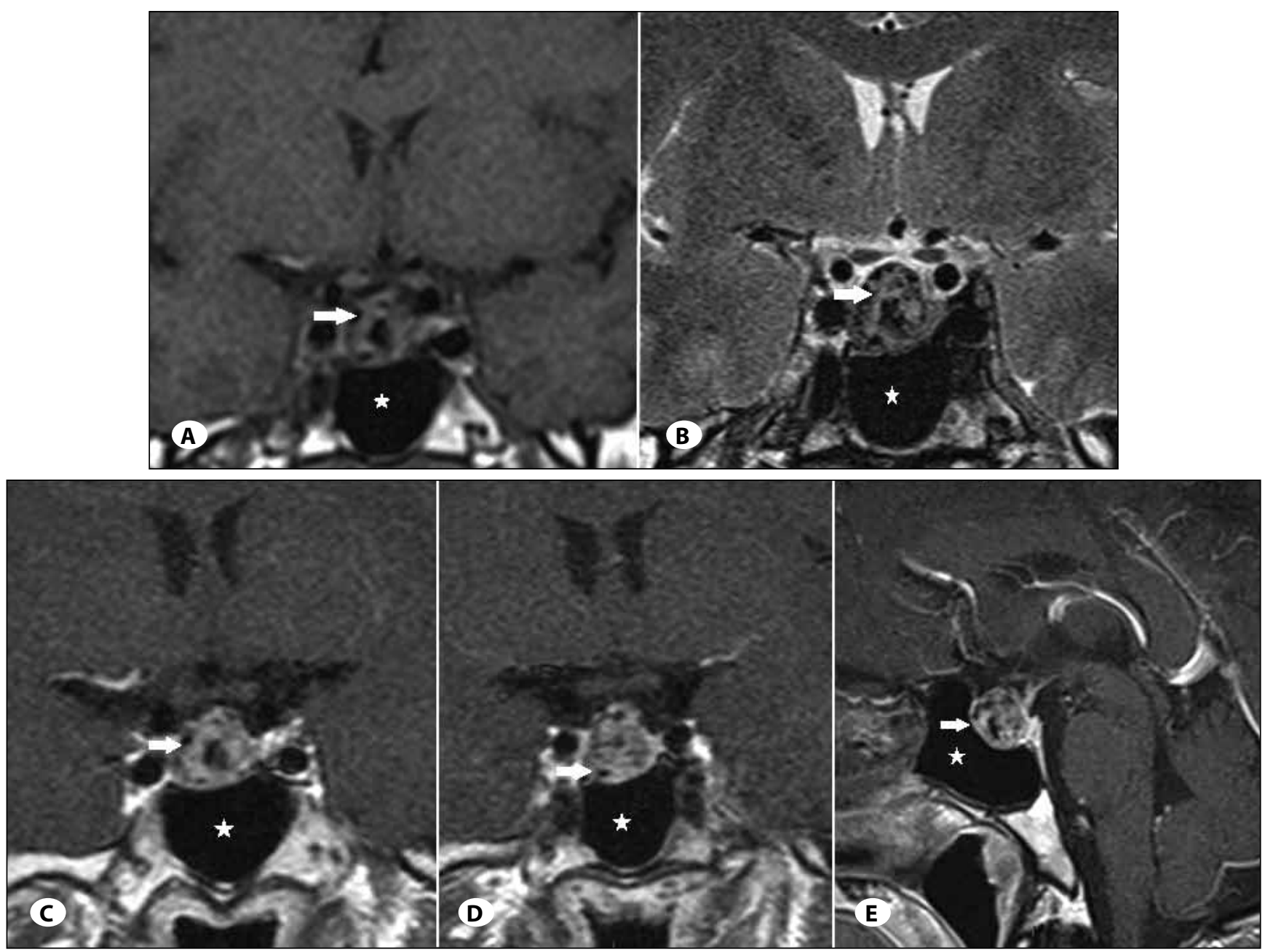

Figure 1: Preoperative magnetic resonance imaging. Coronal A) T1- and B) T2-weighted images both reveal a slightly hyperintense lesion with sparse hypointense nodularity. The lesion was showing minimal suprasellar extension but no invasion of the cavernous sinuses. C,D) Coronal and E) sagittal sections after gadolinium administration show that the lesion was enhancing heterogeneously. Arrow: the pituitary stone, Star: the sphenoid sinus. 

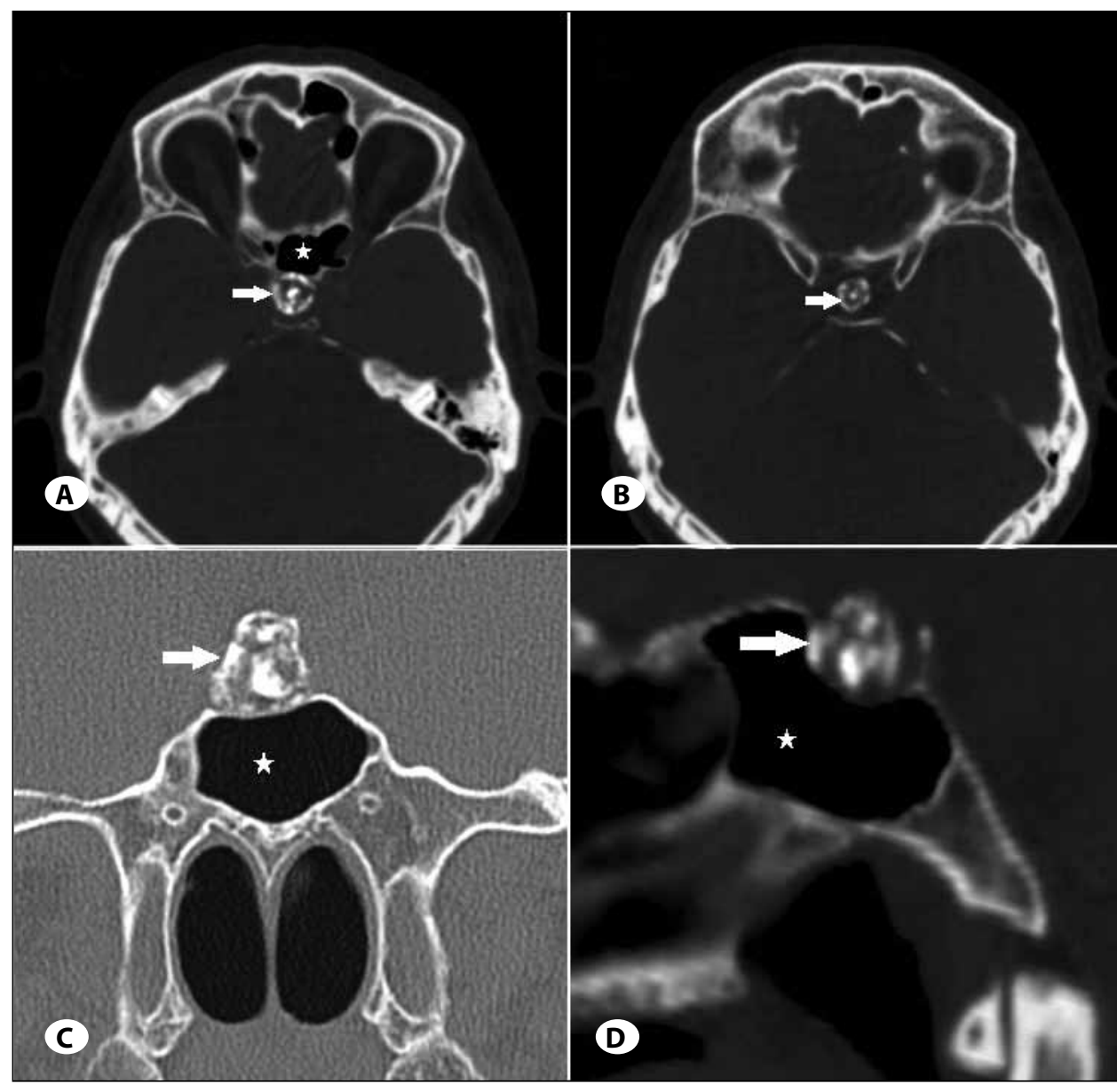

Figure 2: Preoperative computed tomography. A,B) Axial, C) coronal, and D) sagittal scans in bone window show near total calcification of the lesion.

Arrow: the pituitary stone, Star: the sphenoid sinus.

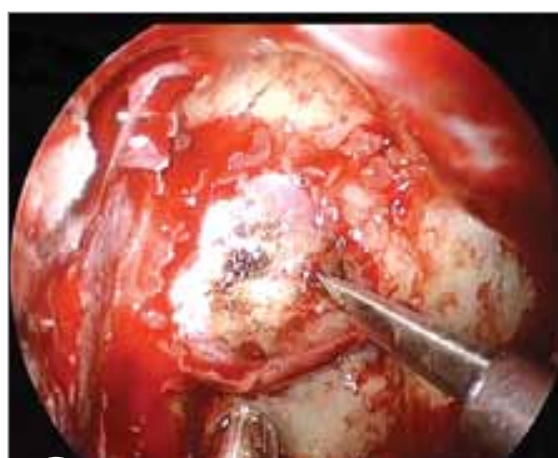

(A)

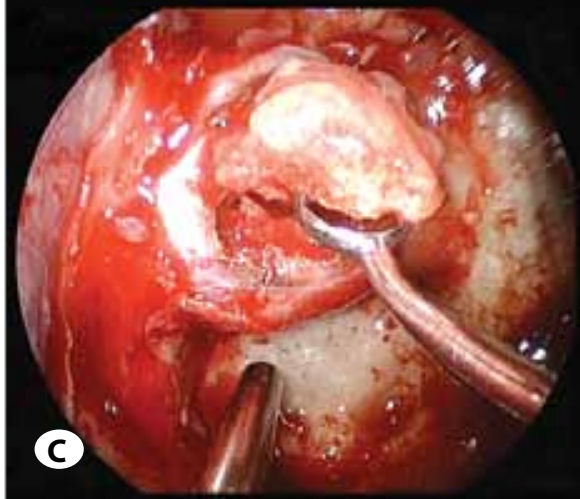

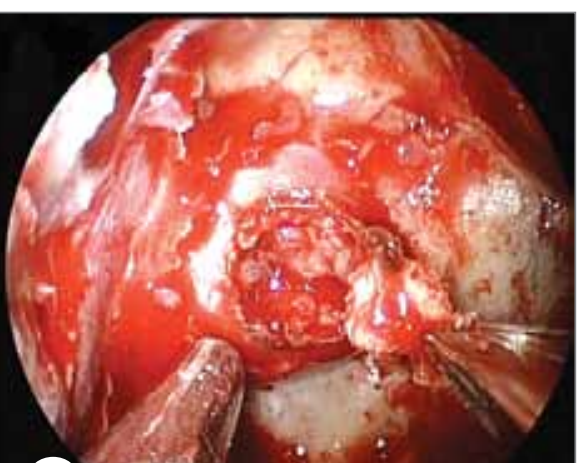

B

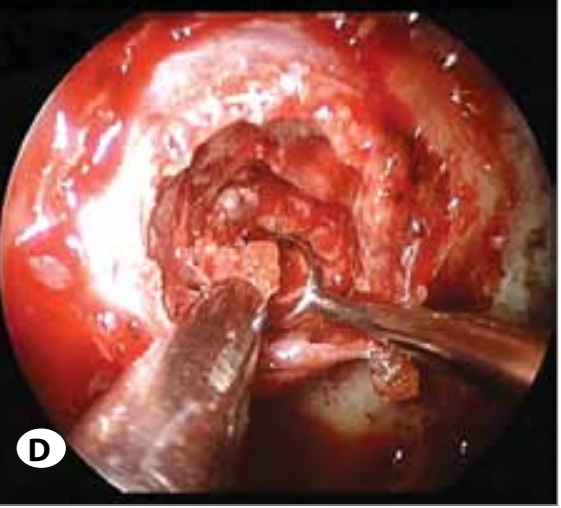

Figure 3: A) Intraoperative view. Opening of the duramater. B) Sellar lesion with stone-like consistency was attached to duramater. First piece of the lesion was removed with the duramater. C,D) Total resection of the lesion was achieved by piecemeal removal. 

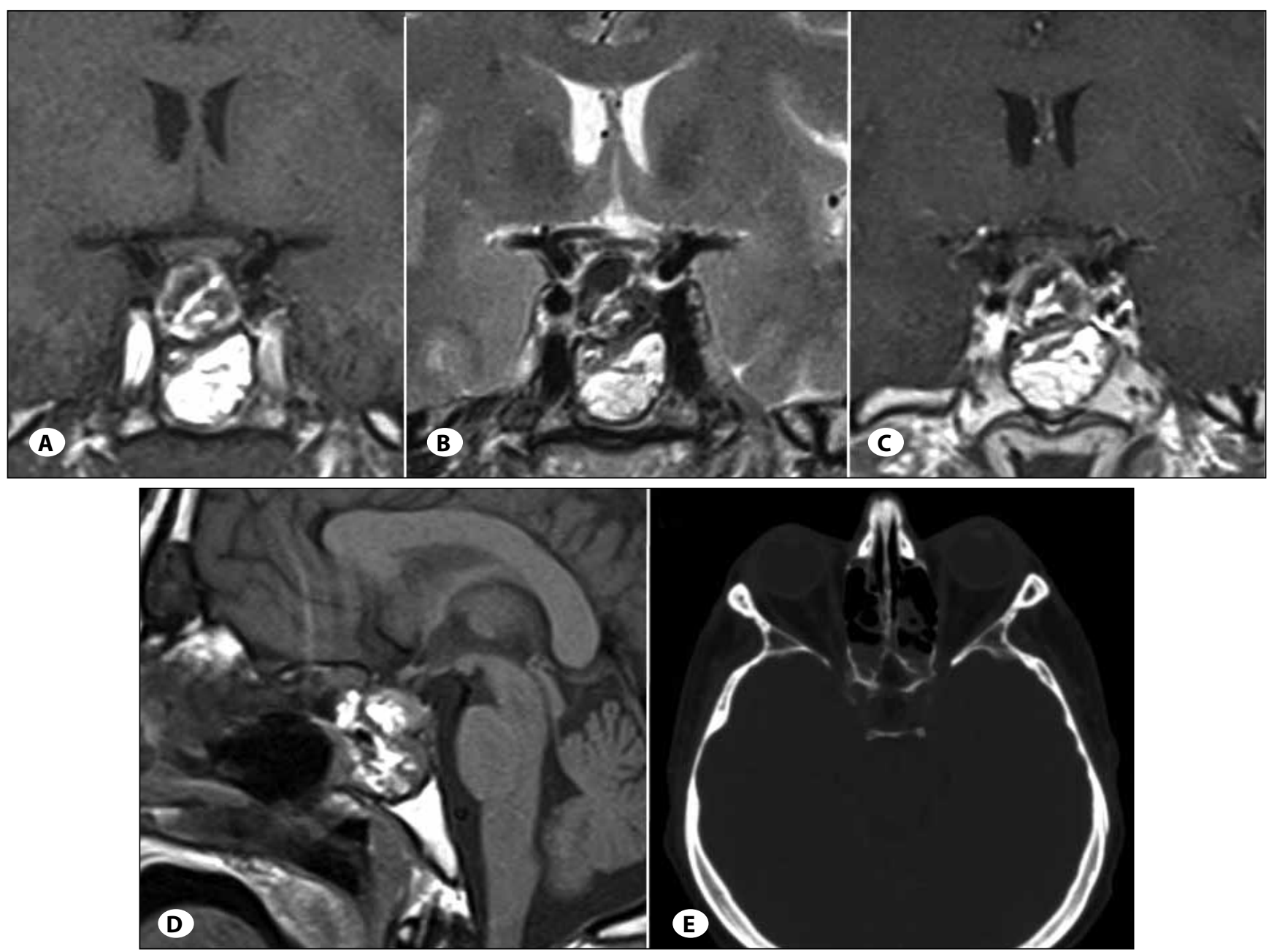

Figure 4: Postoperative magnetic resonance imaging (MRI) and computed tomography (CT). On the MRI of the patient, coronal A) T1- and B) T2-weighted images (respectively), C) coronal section after gadolinium administration, and D) sagittal T1-weighted image proved total removal of the lesion. The sella and sphenoid sinus were filled with fat tissue to prevent CSF leak. E) Axial CT scan in bone window showed complete removal of the calcified lesion.

Until now, only eighteen cases have been reported in the English literature (Table II). In sixteen of 18 cases, including our case, these deposits are formed only by calcifications $(2,3,5,7,11,14-16,20,23,25)$. However, on rare occasions, ossification of the adenoma can be present $(13,18)$. Therefore, we found it useful to classify pituitary stones into two groups by their histological findings: Type 1, pituitary stones formed by prominent calcification and Type 2, pituitary stones formed by osteoid metaplasia.

Pathophysiological mechanisms behind both types remain yet to be understood. Hormones secreted by the adenoma and factors involved in the vascularization of the tumor have been proposed to play important role $(2,17)$. Rilliet et al. stated about $75 \%$ of calcified pituitary adenomas are prolactinomas (21). Additional reports also suggested that prolactinomas are more likely to form calcifications and proposed that increased levels of PRL may be the cause of pituitary stones $(2,8,15)$. Rasmussen et al. reported in a series of 73 hyperprolactinemic women that eight patients had calcareous deposits in sellar region (Note that we considered only three of this eight cases as a pituitary stone due to the size and shape of the calcifications) (20). However, review of all cases with a pituitary stone showed only four (25\%) of 16 cases with type 1 pituitary stones were formed within a PRL secreting adenoma (Table II) $(2,20)$. This lead us to that excessive PRL secretion may not be the main mechanism for type 1 pituitary stones. On the other hand, numerous reports have proposed pituitary apoplexy as the possible cause of pituitary stones $(7,8,23)$. Degenerative changes, which have been reported to be common in pituitary apoplexy, may lead to massive calcifications within the pituitary adenoma (8). Additionally, although pituitary apoplexy may present with alarming signs and symptoms, silent apoplexy with no or minimal symptoms has also been described and may be chronic enough to compose a pituitary stone (7). 
Table II: Reports of Pituitary Stones in the Literature Classified in Accordance to Histopathological Type

\begin{tabular}{|c|c|c|c|}
\hline Histopathological classification & $\begin{array}{l}\text { Immunohistochemical } \\
\text { classification }\end{array}$ & $\begin{array}{c}\text { Total number of cases } \\
(\%)\end{array}$ & Article \\
\hline \multicolumn{4}{|l|}{$\begin{array}{l}\text { Pituitary stones formed by } \\
\text { prominent calcification (Type 1) }\end{array}$} \\
\hline & PRL positive & $4(25 \%)$ & $\begin{array}{l}\text { Carapella et al. } 1983 \\
\text { Rasmussen et al. } 1990\end{array}$ \\
\hline & GH positive & $3(19 \%)$ & $\begin{array}{c}\text { Kahan et al. } 1948 \\
\text { Tamaki et al. } 2000 \\
\text { Georghiu et al. } 2008\end{array}$ \\
\hline & TSH positive & $2(12.5 \%)$ & Webster et al. 1994 \\
\hline & ACTH positive & $2(12.5 \%)$ & $\begin{array}{l}\text { La Civita et al. } 1989 \\
\text { Korchi et al. } 2012\end{array}$ \\
\hline & none & $4(25 \%)$ & $\begin{array}{l}\text { Di Chiro et al. } 1975 \\
\text { Chambers et al. } 1976 \\
\text { Kertmen et al. } 2010\end{array}$ \\
\hline & PRL, TSH, and GH positive & $1(6 \%)$ & Present case. 2013 \\
\hline \multicolumn{4}{|l|}{$\begin{array}{l}\text { Pituitary stones formed by osteoid } \\
\text { metaplasia (Type 2) }\end{array}$} \\
\hline & PRL positive & $2(100 \%)$ & $\begin{array}{l}\text { Mukada et al. } 1987 \\
\text { Ke et al. } 2010\end{array}$ \\
\hline
\end{tabular}

The mechanism for type 2 pituitary stones is also unclear. Six cases of pituitary adenomas with ossification have been described before $(9,13,18,19,22,26)$. However, only two of these cases, which both were PRL-secreting adenomas, showed extensive ossification and therefore were in concordance with the diagnosis of a pituitary stone due to their sizes $(13,18)$. Another four cases, 2 with $\mathrm{GH}$-secreting adenomas $(19,22)$ and 2 with gonadotropin-secreting adenomas $(9,26)$, had calcareous deposits mostly in egg-shell form; therefore, they were not considered as pituitary stones.

Various reports have proposed several possible causes of ossification. The animal study of Clement-Lacroix et al. showed PRL has an effect on osteoblasts and so on normal bone formation (4). However, based on diversity of hormones secreted in six cases, Jaiswal et al. have recently concluded that the mechanism behind osteoid metaplasia may not be related to only one hormone (9). In an earlier case report, Mukada et al. suggested that intratumoral bleeding and tumor cell degeneration due to previous gonadotropin treatment might have provoked the ossification (18). Zahariadis et al. held insufficient blood supply of the large tumor in their case responsible for ossification (26). Thus, it seems, similar to as in type 1 pituitary stones, hypersecretion of PRL may not be the main cause of osteoid metaplasia, but due to the effects of PRL on osteoblast, we may assume that PRL has a role in excessive ossification and consequently the formation of a pituitary stone as it is in two cases of PRL-secreting adenomas.

Differential diagnosis of calcified lesions in the sellar region includes pituitary adenomas, meningiomas, craniopharyngi- omas, and more uncommonly chordomas, chondrosarcomas, teratomas, and aneurysms $(1,13,26)$. Meningiomas are the second most common lesions in the sellar region just after pituitary adenomas and are more likely to calcify than pituitary adenomas, but they may have a dural tail and are mostly suprasellar lesions rather than pure sellar $(6,10,24)$. Therefore, meningioma was excluded since our case was pure intrasellar with no sign of dural tail. Since calcification is more commonly seen in craniopharyngiomas, of which $45-57 \%$ show calcifications, our preliminary diagnosis was a craniopharyngioma (12). However, in the light of ultimate diagnosis of the presented case, pituitary stones should also be taken into consideration in differential diagnosis of calcifying tumors in the sellar region.

Carapella et al. stated hormone secretion may continue despite total calcification of the pituitary adenoma (2). Therefore, total removal of pituitary stones should be the goal of the treatment. We believe that neuroendoscopy provides an excellent intraoperative view and promotes easy handling and removal of these tumors.

\section{CONCLUSION}

To our knowledge, this is the first case report of a pituitary stone originating from a mixed-hormone secreting pituitary adenoma. Moreover, for the first time, a pituitary stone has been removed via endoscopic endonasal transsphenoidal route. Additionally, we proposed a classification of pituitary stones based on review of the previously published cases to have a better understanding of the pathophysiological mechanisms behind this clinical phenomenon. 


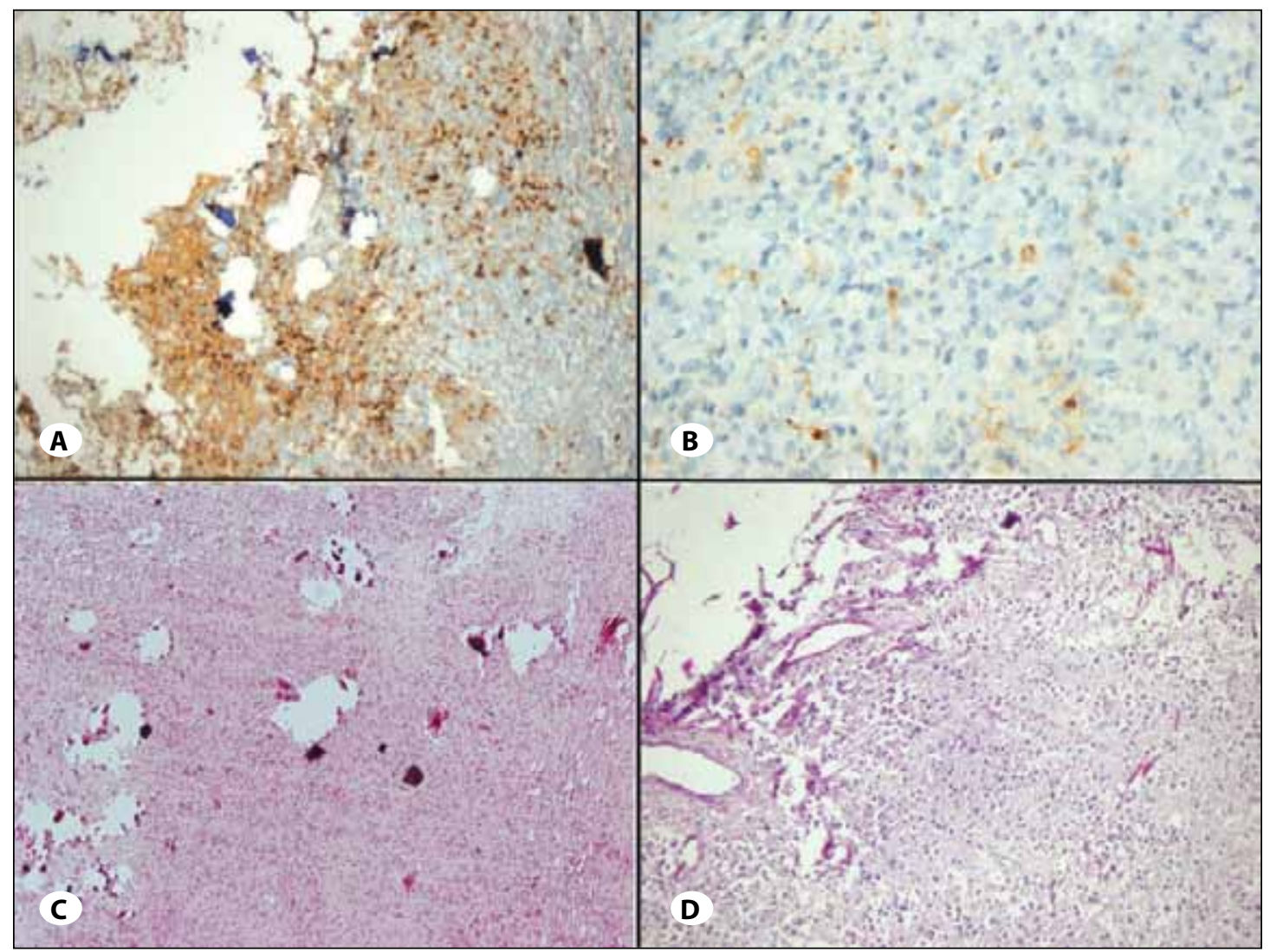

Figure 5: A) Immunohistochemical staining. Prolactin secreting cells in adenoma (PRL x40), B) $\beta$-TSH secreting cells in adenoma (TSH $\mathrm{x} 100)$, C) Dense dystrophic calcification in pituitary adenoma (H\&E x40), D) Another dystrophic calcification area in pituitary adenoma $(\mathrm{H} \& \mathrm{E} \times 40)$.

\section{REFERENCES}

1. Abele TA, Yetkin ZF, Raisanen JM, Mickey BE, Mendelsohn DB: Non-pituitary origin sellar tumours mimicking pituitary macroadenomas. Clin Radiol 67:821-827,2012

2. Carapella CM, Pompei P, Mastrostefano R, Occhipinti E, Rocco A, Falaschi P: Calcified pituitary adenoma associated with severe hyperprolactinemia. Case report. J Neurosurg 59: $871-874,1983$

3. Chambers AA, Lukin R, Tsunekawa $\mathrm{N}$ : Calcification in a chromophobe adenoma. Case report. J Neurosurg 44: 623-625,1976

4. Clement-Lacroix $P$, Ormandy $C$, Lepescheux L, Ammann $P$, Damotte D, Goffin V, Bouchard B, Amling M, Gaillard-Kelly M, Binart N, Baron R, Kelly PA: Osteoblasts are a new target for prolactin: Analysis of bone formation in prolactin receptor knockout mice. Endocrinology 140:96-105,1999

5. Di Chiro G, Saldino R, McGuffin WL Jr, Sachson RA, Gorden P, Bartter FC: Pituitary stones. Ann Intern Med 83:66-69,1975

6. Donovan JL, Nesbit GM: Distinction of masses involving the sella and suprasellar space: Specificity of imaging features. AJR Am J Roentgenol 167:597-603,1996
7. Georghiu ML, Niculescu D, Dumitrascu A, Coculescu M: Pituitary stone in long-standing acromegaly with spontaneous remission. Acta Endocrinologica (Buc) 4: 203-210,2008

8. Horiuchi T, Tanaka Y, Kobayashi S, Yokoh A, Unoki T: Total capsular calcification in a prolactinoma--case report. Neurol Med Chir (Tokyo) 36:729-732,1996

9. Jaiswal S, Vij M, Jaiswal AK, Chand G, Behari S, Kumarjain V: Ossifying pituitary adenoma co-existing with astrocytoma and pituitary adenoma associated with gangliocytoma: Two unusual conditions. Turk Neurosurg 22:127-133,2012

10. Johnsen DE, Woodruff WW, Allen IS, Cera PJ, Funkhouser GR, Coleman LL: MR imaging of the sellar and juxtasellar regions. Radiographics 11:727-758,1991

11. Kahan A: Acromegaly and pluriglandular dysfunction showing calcification of pituitary. Proc R Soc Med 41:655,1948

12. Karavitaki N, Cudlip S, Adams CB, Wass JA: Craniopharyngiomas. Endocr Rev 27:371-397,2006

13. Ke C, Deng Z, Lei T, Zhou S, Guo DS, Wan J, Wu S: Pituitary prolactin producing adenoma with ossification: A rare histological variant and review of literature. Neuropathology 30:165-169,2010

14. Kertmen $\mathrm{H}$, Turkoglu E, Baskaya MK: A calcified sellar lesion. J Clin Neurosci 17:897, 956,2010 
15. Korchi AM, Momjian S, Vargas MI: Corticotroph pituitary stone. Can J Neurol Sci 39:89-90,2012

16. La Civita KA, McDonald S, Jacobson J: Cyclic Cushing's disease in association with a pituitary stone. South Med J 82:11741176,1989

17. Landolt AM, Rothenbuhler V: Pituitary adenoma calcification. Arch Pathol Lab Med 101:22-27,1977

18. Mukada K, Ohta M, Uozumi T, Arita K, Kurisu K, Inai K: Ossified prolactinoma: Case report. Neurosurgery 20:473-475,1987

19. Palaoglu S, Bavbek M, Peker S, Onol B, Sungur A, Erbengi A: Ossified somatotropinoma. Surg Neurol 41:143-146,1994

20. Rasmussen C, Larsson SG, Bergh T: The occurrence of macroscopical pituitary calcifications in prolactinomas. Neuroradiology 31:507-511,1990

21. Rilliet B, Mohr G, Robert F, Hardy J: Calcifications in pituitary adenomas. Surg Neurol 15:249-255,1981
22. Roncaroli F, Fioravanti A, Marliani AF, Calbucci F: Osseous metaplasia in a growth hormone-secreting pituitary adenoma. Clin Neuropathol 18:205-207,1999

23. Tamaki T, Takumi I, Kitamura T, Osamura RY, Teramoto A: Pituitary stone-case report. Neurol Med Chir (Tokyo) 40: 383-386,2000

24. Taylor SL, Barakos JA, Harsh GR 4th, Wilson CB: Magnetic resonance imaging of tuberculum sellae meningiomas: Preventing preoperative misdiagnosis as pituitary macroadenoma. Neurosurgery 31:621-627; discussion 627,1992

25. Webster J, Peters JR, John R, Smith J, Chan V, Hall R, Scanlon MF: Pituitary stone: Two cases of densely calcified thyrotrophin-secreting pituitary adenomas. Clin Endocrinol (Oxf) 40:137-143,1994

26. Zahariadis G, Kontogeorgos G, Liberopoulos K, George S, Kovacs K: Ossifying pituitary gonadotroph adenoma: A case report. Acta Neurochir (Wien) 141:1001-1003; discussion 1004,1999 